\title{
Understanding Millenials' Intention to Use E-Money: A Study of Students' University in Padang
}

\author{
Reno Fitri Meuthia ${ }^{1}$, Rangga Putra Ananto ${ }^{2}$, Zalida Afni ${ }^{3}$, llham Setiawan ${ }^{4}$ \\ \{enofm87@gmail.com ${ }^{1}$,rangga_delavega@yahoo.com², zalida.afni@yahoo.com ${ }^{3}$ \} \\ Accounting Department, Politeknik Negeri Padang ${ }^{1234}$
}

\begin{abstract}
The purpose of this study is to analyze the relation of factors which influence emoney adoption among millennials in Indonesia especially in Padang, West Sumatra. A model is proposed with five factors: performance expectancy, effort expectancy, social influence, facilitating conditions (from UTAUT model) which impact intention to use an emoney. The sample is consisted of 179 millennials e-money users accessed through a survey in Padang. Results of the study show that all independent variables (performance expectancy, effort expectancy, social influence and facilitating conditions) have direct significant effects on intention to use e-money among millennials in Padang.
\end{abstract}

Keywords: E-Money, Technology Acceptance, the Unified Theory of Acceptance and Use of Technology (UTAUT), Millennials

\section{Introduction}

E-Money (electronic money) is relatively a new financial innovation for payment transaction in Indonesia. E-money was introduced in 2007 and was classified into card-based products/prepaid card and software based product. The benefits of using electronic money as micro payment instruments are to reduce money printing fees, security and lost risk, and to provide convenience in transaction for customer [1]. The number of mobile phone user is arise recently, and become a part of daily life. Many services are available to accommodate a modern lifestyle. Mobile phones today not only use as communication tools but also serve an advance feature like mobile payment. Mobile payment services as one of e-money payment refer to all payments for goods, services, and bills authorized, initiated, or realized with a mobile device [2]. Since 2012, e-money service has increased in Indonesia. Not only provided by banks and telecommunication companies, apps developers but also taking part in e-money services. In the future, it is expected to be the easiest and the most convenient way of payment method.

To investigate the e-payment habit in Indonesia, in 2017 the Daily Social has conducted an electronic survey, asking 1059 respondents, sampled proportionally from among Indonesian smartphone users throughout Indonesia. Based on the survey, about 30\% respondents never use e-money in any form. In October 2017, the government has declared that all toll road transaction must be fully electronic. This action was taken to increase the utilization of epayment in Indonesia. The regulation was success to raise the usage of e-money. Almost 300\% rise of e-money transaction were recorded but unfortunately it only happened in big cities [1]. Changing customer's way of thinking and habit is not easy because some people are 
inconvenient changing their usual way of life. The decision makers need to understand the characteristics of the community so they can easily to communicate or introduce the new technology.

There are many aspects that influence a technology adoption, such as personal factor, education, social and economic and also culture [3]. In order to create cashless society, the government needs to take an action, educating people to use the e-money. The government also needs to open more access to the bank. One of the reasons, most economic transactions are still using cash in Indonesia because not everybody has an access to the bank especially those who live in rural area. According to the Central Bureau of Statistics Office release, Indonesian Gross Domestic Saving Rate was only $34.8 \%$ in 2015. It was far below other countries in South East Asia, for example Singapore was 49\% and Philippine was $46 \%$. Moreover, the government has made an act to increase the saving rate in order to encourage the cashless transaction among nations. The existence of Gojek, a unicorn form Indonesia that dealing with transportation service, food purchasing and payment service become an prominent point of e-money development in Indonesia. Gojek serves some major cities in Indonesia and people a enjoy using their apps because it offers some benefit to customer. However, cash transaction is still dominating in Indonesia generally.

The millennials are a generation of young people. This generation was born between 1980 and 2000 [4]. The millennials now become a large population and their purchasing power is making them an attractive target for many consumer industries, including e-money provider. This generation was born in emerging world of technology, and they were reported as active user of all form of social media and communication like cellphones, internet, computers, text messaging, video games, etc. The millennials are digitally more active than any previous generation since they are permanently connected to each other through digital media. Millenials spend more but less loyalty to the brands than previous generations [5]. They use brands to create images, to represent their personality and communicate their value [6]. They also prefer to spend money on experiences rather than materialistic stuffs [7]. With these characters, millennials would like to use e-money because it more convenient, suit to their lifestyle and give more promotions rather than cash payment transaction.

The UTAUT model originally used to investigate individual acceptance of information technology [8]. UTAUT analyses the critical factors related to prediction of the behavioral intention to use a technology. UTAUT states that there are three determinants of intention to use (Performance Expectancy, Effort Expectancy and Social Influence) and two direct determinants of usage behavior (Behavioral Intention and Facilitating Condition) [9]. Applying the UTAUT in a new context such as new user population, new cultural setting, etc will expand its contribution to generalization of the model.

\section{Methodology}

This study use the Unified Theory of Acceptance and Use of Technology (UTAUT) by Venkantesh. The UTAUT model was developed on the ground assumption that the intention to use a certain technology is affected by some beliefs such as performance expectancy, effort expectancy, social influence, facilitating conditions and intention to use. The development of the hypotheses are described as follow: 


\section{Performance Expectancy (PE)}

Performance expectancy is defined as "the degree to which an individual believes that using the system will help him or her to attain gains in job performance." [8]. Customers, who believe that e-money as helpful in completing payment process compared to the traditional methods of payment, will most likely have a strong intention to use the technology [10]. According to Miliani et al [11], customer use e-money as payment method because of benefit of e-money that saving time and efficient than cash payment. Based on those arguments, the following hypothesis is proposed :

$\mathrm{H}_{1}$ : $\quad$ Performance expectancy has a positive effect in intention to use e-money

\section{Effort Expectancy (EE)}

Effort expectancy is defined as "the degree of ease of associated with the use of the system."'[8]. Consumers who perceive the e-money as easy to use will have strong intention to use the e-money in daily life [10]. Previous research has been settled easiness, velocity and efficiency as motivation of user to use e-money[1],[11]. Based on the theory, we posit the following hypothesis :

$\mathrm{H}_{2}$ : $\quad$ Effort expectancy has a positive effect in intention to use e-money

\section{Social Influence (SI)}

Social influence is defined as the perceived social pressure from close members to the individual to perform or not perform the specific behavior[10]. Millenials as an active user of social media platform will share the information through the social media. They will follow the trend from their close friends or even the influencer. Digital media advertising also give more information about the benefit like coupon or discount using or buying certain product [12]. Based on the arguments, we posit the following hypothesis:

$\mathrm{H}_{3}$ : $\quad$ Social Influence has a positive effect in intention to use e-money

\section{Facilitating Condition (FC)}

Facilitating condition is described as factors that help users to adopt a new technology, such as guidance or instruction for users[8]. A reliable support system becomes a crucial thing when some potential users decide to adopt a new technology. Based on those arguments we draw the hypothesis as follow :

$\mathrm{H}_{4}$ : $\quad$ Facilitating conditions has a positive effect in intention to use e-money 


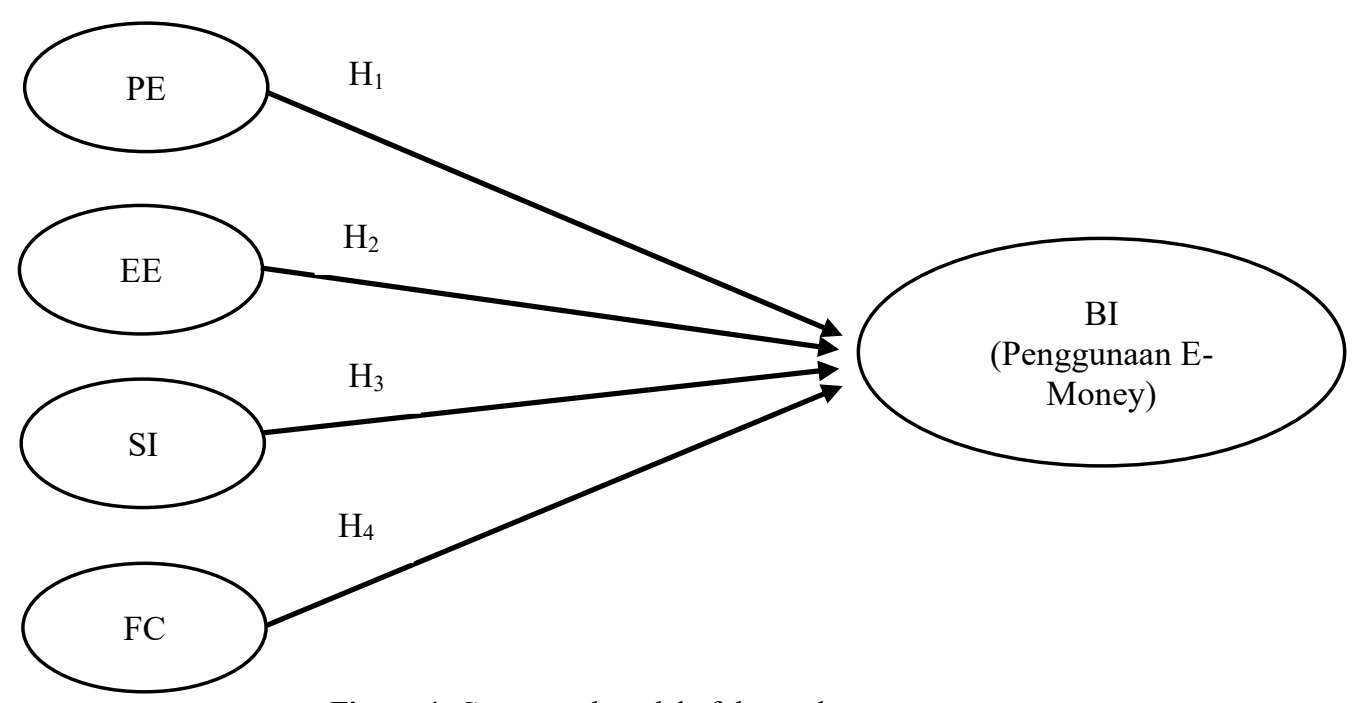

Figure 1. Conceptual model of the study

\section{Instrument development and Data Collection}

The questionnaire employed to collect data had three sections. The first section was a screening question. In this part, respondents were asked whether they live in Padang and actively use e-money on regular basis. The second section is used to collect respondents' demographic information including gender, age, level of education, university name, monthly expenditure, brand of e-money used and how they spend their e-money regularly. The third section included consumers percepcions regarding factors that influence their behavioral intention (BI) to adapt e-money such as : performance expectancy (PE), effort expectancy (EE), social influence (SI) and facilitating condition (FC). Items that measure BI, PE, EE, SI and FC were adopted from Venkantesh et al[8].

The survey questionnaire was available in google form and use Indonesian language. The questionnaire was tested through a pilot survey on a sample of 30 respondents and only had few minor modification. The final version of the questionnaire was administered online through social media apps to the university students in Padang. A request was made to all recipients to forward the survey link to their friends. Data collection began in August 2019 and ended in September 2019, with 250 questionnaires returned and completed. The nonprobabilistic convenience sample used in this study was considered appropriate due to preliminary nature of the research[13].

Participants responded to statements on five point Likert scale, which ranged from strongly agree to strongly disagree. A total of 250 completed questionnaires were returned. Seventy one questionnaires were discarded because of unmatch criteria, leaving 179 usable questionnaires for this study. The data analyses were performed using the SPSS ver. 20. The table 1 describes the characteristics of respondents in details. 
Table 1 : Demographic data of the sample

\begin{tabular}{|c|c|c|c|}
\hline \multirow[t]{2}{*}{ Attributes } & \multirow[t]{2}{*}{ Categories } & \multicolumn{2}{|c|}{ Respondents } \\
\hline & & Frequency & Percentage $(\%)$ \\
\hline \multirow[t]{2}{*}{ Gender } & Male & 52 & 29 \\
\hline & Female & 127 & 71 \\
\hline Age & $19-28$ & 179 & 100 \\
\hline \multirow[t]{7}{*}{ University } & Politeknik Negeri Padang & 106 & 59,2 \\
\hline & Univeristas Negeri Padang & 30 & 16,9 \\
\hline & Universitas Andalas & 17 & 9,5 \\
\hline & UPI YPTK & 13 & 7,3 \\
\hline & Universitas Baiturahmah & 6 & 3 \\
\hline & Universitas Dharma Andalas & 5 & 2 \\
\hline & Universitas Bung Hatta & 3 & 1,9 \\
\hline \multirow[t]{8}{*}{ E-money brand* } & Gopay & 149 & $83,2 * *$ \\
\hline & OVO & 82 & $46,8^{* *}$ \\
\hline & Dana & 55 & $30,7 * *$ \\
\hline & BRI Brizzi & 26 & $14,5^{* *}$ \\
\hline & Link Aja & 24 & $13,4 * *$ \\
\hline & BCA Flazz & 20 & $11,1 * *$ \\
\hline & Mandiri e-money & 9 & $5^{* *}$ \\
\hline & BNI Tapcash & 8 & $4,5 * *$ \\
\hline Monthly & Less than 1000000 & 72 & 40,2 \\
\hline \multirow[t]{3}{*}{ Expenditure (IDR) } & $1000000-1500000$ & 92 & 51.4 \\
\hline & $1550000-2000000$ & 10 & 5,6 \\
\hline & Over 2050000 & 5 & 2,8 \\
\hline Spending & Transportation & 158 & $88,2 * *$ \\
\hline \multirow{5}{*}{ Allocation* } & Telephone and Internet & 143 & $79,9 * *$ \\
\hline & Online shopping & 100 & $55,9 * *$ \\
\hline & Offline shopping & 98 & $54,7 * *$ \\
\hline & Billing & 71 & $39,6 * *$ \\
\hline & Entertainment & 59 & $33 * *$ \\
\hline
\end{tabular}

*Respondents can choose more than one option.

**Percentage based on total respondents

About seventy one percent of respondents are female while only twenty nine percent respondents are male. All respondents age are ranged from 19-28, so they are all represents the millennial generation. More than fifty percent respondents are students of Politeknik Negeri Padang, other respondents are from all reputable university in Padang. Most respondents spend less than 1500000 (IDR) per month. Only fifteen students $(8,4 \%)$ spend more than 1500000 (IDR) in a month. The largest percentage of students' spendings are transportation, both online and city bus fare $(88,2 \%)$ and telephone credit and internet top up $(79,9 \%)$. Other biggest spending of the students are shopping, both online $(55,9 \%)$ and offline shopping $(54,7)$. The latest, only about $33 \%$ students use their e-money for entertainment such as game online and buy a movie ticket online. 


\section{Result and Discussion}

\section{Reability and Validity Analysis}

The content of survey questionnaire evaluated by conducting reliability analysis using Cronbach's Alpha score, the most widely use for measuring content validity[14]. In reliability analysis, the Cronbach Alpha coeffisient must be larger than 0.6 [15] and the correted item to total correlation must be larger than $r_{\text {table }}(0.146)$. Table 2 and Table 3 illustrates the results of reliability and correlation matrix, respectively. Table 4 showthe results of collinearity statistics. From the above criteria, all factors were reliable and acceptable. And there is no multicollinearity because Tolerance vakues are above 0.1 and VIF is less dan 10 . Thus, it could be concluded that the construct of this study were reliable and valid.

Table 2 :Reliability analysis of developed scales

\begin{tabular}{llc}
\hline Research Construct & \multicolumn{1}{c}{ Factors } & $\begin{array}{c}\text { Cronbach } \\
\text { Alpha }\end{array}$ \\
\hline Motivation & Performance Expenctancy (PE) & 0,777 \\
& Effort Expectancy (EE) & 0,834 \\
& Social Influence (SI) & 0,878 \\
E-money use & Facilitating Condition (FC) & 0,838 \\
& Behavioral Intention (BI) & 0,864 \\
\hline
\end{tabular}

Table 3 : Correlation Matrix

\begin{tabular}{lccccc}
\hline & $\mathbf{1}$ & $\mathbf{2}$ & $\mathbf{3}$ & $\mathbf{4}$ & $\mathbf{5}$ \\
\hline $\mathbf{P E}$ & 1.0000 & & & & \\
$\mathbf{E E}$ & $0.505^{* *}$ & 1.000 & & & \\
SI & $0.528^{* *}$ & $0.386^{* *}$ & 1.000 & & \\
FC & $0.633^{* *}$ & $0.519^{* *}$ & $0.691^{* *}$ & 1.000 & \\
BI & $0.746^{* *}$ & $0.550^{* *}$ & $0.658^{* *}$ & $0.781^{* *}$ & 1.000 \\
\hline
\end{tabular}

**Correlation is significant at the 0.01 level (2-tailed)

Table 4 : Collinearity Statistics

\begin{tabular}{lcc}
\hline & Tolerance & VIF \\
\hline PE & 0.499 & 2.005 \\
EE & 0.671 & 1.491 \\
SI & 0.604 & 1.985 \\
FC & 0.392 & 2.553 \\
\hline
\end{tabular}

\section{Hypotheses Testing}

Regression analysis method is used to verify the effect of motivation of e-money use. Beta coefficient is used to measure the effect between four independent variables (performance expectancy, effort expenctancy, social influence and facilitating condition) and intention to use e-money as dependent variable. As shown in Table 5, performance expectancy, social infuence and facilitating condition have significant effects on e-money use for millennials. 
Performance expectancy and facilitating condition have higher Beta value than social influence. It means that performance expectancy and facilitating condition have stronger contribution to the model rather than social influence. Therefore, our result support some of the hypotheses (see table 6). Respondents tend to use e-money when they find certain benefit from the e-money, such as convenient, saving time, improve their productivity and fit their lifestyle. As millennials who have broad experience and knowlegde on internet [16], they don't find difficulties in using new technology such as e-money, so the effort expectancy have no significant effect to use e-money among them. The explanation for this phenomena can be seen in discussion section.

Table 5 : Regression Coefficient

\begin{tabular}{lccc}
\hline Variables & Beta & t-value & sig \\
\hline PE & 0.418 & 6.844 & 0.000 \\
EE & 0.099 & 2.002 & 0.047 \\
SI & 0.101 & 2.708 & 0.007 \\
FC & 0.327 & 6.159 & 0.000 \\
\hline
\end{tabular}

Table 6 : Summary result of hypotheses

\begin{tabular}{lcc}
\hline Variables & Hypotheses & Test Result \\
\hline PE & $\mathrm{H}_{1}$ & Supported (positive and significant) \\
EE & $\mathrm{H}_{2}$ & Supported (positive and significant) \\
SI & $\mathrm{H}_{3}$ & Supported (positive and significant) \\
FC & $\mathrm{H}_{4}$ & Supported (positive and significant) \\
\hline
\end{tabular}

Based on the test results (see Table 5), all independent variables (performance expectancy, effort expectancy, social influence and facilitating condition have strong impact to intention to use the e-money among university students in Padang. These results are consistent with previous research done by Wei [17] [18] that consumers will voluntarily adopt e-money usage when they find the usefulness of the product, convenience and reliable support of the new payment system. Along with its benefit, providers should offers tutorial or guidance to help consumer using the e-money easily. This supporting condition will increase the intention to use e-money among the consumers.

Social influence such as information from friends and family, relative, social media and influencer also have significant effect to the adoption of e-money among millennials. A peer pressure is one of important factor that affect respondent's behavior. Students tend to spend their time with friends, so a friend's opinion is matter to this young generation. As active social media users, millennials have idolizing celebrity or influencer and follow their idol habit. This group of people will influence each other through their opinion or comment about promotion and benefit of using e-money in social media and it will lead to stronger intention to use e-money. 


\section{Conclusion}

Based on the results of the discussion it can be concluded, variable performance expectancy, effort expectancy, social influence, and facilitating condition have a positive and significant effect on behavioral intention of e-money in Padang.

\section{Limitation and Future Research}

The limitation of the study is the sample should be more diversified in term of geographical regions to generalized result to cover Indonesia area. Future studies not only have to expand the coverage area but also explore others factors that affecting the adoption of e-money in Indonesia. In addition, future study can compare intention to adopt e-money among different generation or comparing the usage of e-money between urban and rural area.

\section{References}

[1] Bank Indonesia. 2009. Peraturan Bank Indonesia Nomor 11/11/PBI/2009 tentang Penyelenggaraan Alat Pembayaran dengan Menggunakan Kartu dan Uang Elektronik. www.bi.go.id. Diakses pada Juli 2019.

[2] A Critical Review of Mobile Payment Research. Dahlberg, Tomi, Guo, Jie and Ondrus, Jan. s.l. : Electronic Commerce Research and Application, 2015.

[3] Exploring e-Payment Adoption in Vietnam and Taiwan . Lin , Chinho and Nguyen, Chonghoang. s.1. : The Journal of Computer Information System, 2011.

[4] Lee, N and Kotler, Philip. Social Maketing : Changing Behaviors for Good . s.l.: s. Publication, 2016.

[5] Generation Y Values and Lifestyle Segments. Valentin, D. B and Powers, T. L . 7, s.1. : Journal of Consumer Marketing, 2013, Vol. 30.

[6] The Characterization of the Millennials and Their Buying Behavior. Moreno, Flor Madrigal, et al., et al. Canadian : International Journal of Marketing Studies, 2017, Vol. Vol. 9 No. 5.

[7] Gen Y Customer Loyalty in Online Shopping : An Integrated Model of Trust, User Experience and Branding. A, Bilgihan. November, s.l. : Computers in Human Behavior, 2016, Vol. 61.

[8] User Acceptance of Information Technology : Toward a Unified View. Venkantesh, Viswanath, et al., et al. 3, s.1. : MIS Quarterly, 2003, Vol. 27.

[9] The Integrated Model on Mobile Payment Acceptance (IMMPA) : An Empirical Application to Public Transport. Pietro, L. Di, et al., et al. Roma, Italy : Transportation Research, 2015.

[10] The Moderating Effect of Espoused Cultural Dimensions on Consumer's Intention on Use Mobile Payment Device. Alshare, Khaled A and Mousa, Abeer A. Auckland : c, 2014.

[11] Adoption Behavior of E-Money Usage. Miliani, Lani, Purwanegara, Mustika Sufiati and Indriani, Mia Tantri Diah. 7, s.l. : Information Management and Business Review, 2013, Vol. 5 .

[12] Digital Marketing Strategies that Millennials Find Appealing, Motivating or Just Annoying. Snith, K.T. 6, s.1. : Journal of Strategic Marketing, 2011, Vol. 19.

[13] Sekaran, Uma. Metodologi Penelitian untuk Bisnis. Jakarta : Salemba Empat, 2006.

[14] Ghozali, Imam. Aplikasi Analisis Multivariate dengan Program IBM SPSS 23, Edisi 8. Semarang : Badan Penerbit Universitas DDiponegoro, 2016.

[15] Hair, J.F, et al., et al. Research Methods for Business . New York : John Wiley, 2006.

[16] Interactive Media Usage Among Millennial Consumers. Moore, M. 6, 2012 : Journal of Consumer Marketing, Vol. 29. 
[17] Goh, Sau Wei. Factos Affecting Adoption of E-Payment Among Private Unversity Students in Klang Valley. 2017.

[18] Understanding Consumer Acceptance of Mobile Payment Services : An Empirical Analysis. Schierz, Paul Gerhardt, Schilke, Oliver and Wirtz, Berd W. s.l. : Electronic Research and Application , 2010, Vol. 9.

[19] Dynamic Key Matrix of Hill Cipher Using Genetic Algorithm. Siahaan, Andysah Putera Utama and Rahim, Robbi. 8, 2016, International Journal of Security and its Applications, Vol. 10, pp. 173-180.

[20] 128 Bit Hash of Variable Length in Short Message Service Security. Rahim, Robbi. 1, 2017, International Journal of Security and Its Applications, Vol. 11, pp. 45-58.

[21] Study of Three Pass Protocol on Data Security. Rahim, Robbi and Ikhwan, Ali. 11, 2016, International Journal of Science and Research (IJSR), Vol. 5, pp. 102-104.

[22] Review Report On Security Breaches Using Keylogger And Clickjacking. Pawade, Dipti Y, Lahigude, Abhilasha and Reja, Divya . Special Issue (NCRTIT 2015), 2015, International Journal of Advance Foundation and Research in Computer (IJAFRC), Vol. 2, pp. 55-59.

[23] An Introduction to Undetectable Keyloggers with Experimental Testing. Dadkhah, Mehdi, et al., et al. 3, 2014, International Journal of Computer Communications and Networks, Vol. 4, pp. 1-5.

[24] User Activity Monitoring Using Keylogger. Venkatesh, R and Sekhar, Raja K. 23, 2015, Asia Journal of Information Technology, Vol. 15, pp. 4758-4762.

[25] System Monitoring and Security Using Keylogger . Tuli, Preeti and Sahu, Priyanka . 3, 2013, International Journal of Computer Science and Mobile Computing, Vol. 2, pp. 106-111.

[26] A Survey on Keylogger: A malicious Attack. Pathak, NameHemita , Pawar, Apurva and Patil, Balaji . 4, 2015, International Journal of Advanced Research in Computer Engineering \& Technology (IJARCET), Vol. 4, pp. 1465-1469.

[27] Battering Keyloggers and Screen Recording Software by Fabricating Passwords . Adhikary, Nairit, et al., et al. 5, 2012, I. J. Computer Network and Information Security, Vol. 2012, pp. 13-21.

[28] A Composite Algorithm for String Matching. Dalal, Neha R and Jadhav, Poonam . 7, 2015, International Journal of Modern Trends in Engineering and Research (IJMTER), Vol. 2, pp. 68-73.

[29] Applying Bi-Directional Search Strategy in Selected String Matching Algorithms. Pandey, Grishma and Prajapati, G L. 11, 2016, International Journal of Computer Applications, Vol. 143 , pp. 40-43.

[30] Importance of String Matching in Real World Problems. Soni, Kapil Kumar, Vyas, Rohit and Sinhal, Amit. 6, 2014, International Journal Of Engineering And Computer Science, Vol. 3, pp. 6371-6375.

[31] Symmetric Stream Cipher using Triple Transposition Key Method and Base64 Algorithm for Security Improvement. Nurdiyanto, Heri, Rahim, Robbi and Wulan, Nur. Medan : s.n., 2017. International Conference on Information and Communication Technology 2017.

[32] Combination of the Blowfishand Lempel-Ziv-Welch algorithms for text compression. Rahim, Robbi, et al., et al. 3, 2017, World Transactions on Engineering and Technology Education, Vol. 15, pp. 292-297.

[33] Comparison Searching Process of Linear, Binary and Interpolation Algorithm. Rahim, Robbi, et al., et al. Medan : s.n., 2017. International Conference on Information and Communication Technology 2017.

[34] Faktor-Faktor yang Mempengaruhi Penggunaan E-Money pada Generasi Milenial. Suwandi, Muhammad Abdurrahim and Azis, Elvira. 2018.

[35] Ekawati, Desi Kurnia. Analisis Faktor-Faktor yang Mempengaruhi Penggunaan Telkomsel Cash (T-Cash) di Yogyakarta. 2018. 